\title{
Research on Teaching Reform of Business Administration Major in Colleges and Universities under "Internet + Education"
}

Yuanyuan Zhou

Xinyang Normal University 464000

Project Fund: Key Project of Henan Higher Education Teaching Reform Research and Practice: Research and Practice on the Reform Of business Administration Personnel training System in local Universities under the Background of internet+ (Project No:2019SJGLX118), This paper is supported by the young key teachers program of Xinyang Normal University from 2017 to 2020.

Abstract: The theoretical content and practical content of the business management major in colleges and universities are very rich. It is very difficult to combine the two organically. Therefore, this also brings many difficulties to actual teaching. With the increasing development of information technology, "Internet + education" has effectively changed the problems of lack of resources, limited time, and lack of student interest in traditional teaching, and has effectively improved the quality of education and teaching in various subjects. This article conducts research and discussion on the reform of college business administration teaching under the background of "Internet + education".

Keywords: Internet + Education; Business Administration Major; Teaching Reform

"Internet + education" is an organic combination of Internet technology and college education and teaching, so that students can realize mobile learning through the Internet, eliminating the limitations of traditional teaching time and space. In addition, online teaching also allows students to study independently according to their own learning progress, and greatly enriches the learning content of students, and effectively enhances their enthusiasm for learning. Combining years of experience in business administration teaching, the author first studied the influence of "Internet + education" on the teaching activities of business administration, then analyzed its application status, and finally conducted a special teaching reform discussion on the problems found, aiming to better To improve the teaching quality of my country's business administration major, and provide students with better education and teaching services.

\section{The influence of "Internet + education" on teaching activities of business administration}

The rapid development of Internet information technology has made people's work and life more efficient and faster, effectively improved social productivity, and once entered the fast lane of human development. "Internet + education" also came into being under this background. Its appearance has brought a huge impact on traditional education and teaching, fundamentally changed the traditional teaching form, and truly realized the liberalization of education and learning. The promotion of the concept of lifelong education for all has a very positive impact. However, the author conducts a simple research and analysis on the impact of "Internet + education" on the teaching activities of business administration majors, which can be mainly expressed in the following points: First, the use of Internet technology in education and teaching can make teaching resources better. Let student learning and teacher teaching become more liberalized, making college business management professional teaching more diversified. Secondly, the establishment of the network teaching platform has enriched teaching resources and effectively expanded the practical teaching of

Copyright (C) 2020 Yuanyuan Zhou

doi: 10.18282/le.v9i7.1459

This is an open-access article distributed under the terms of the Creative Commons Attribution Non-Commercial License

(http://creativecommons.org/licenses/by-nc/4.0/), which permits unrestricted non-commercial use, distribution, and reproduction in any medium, provided the original work is properly cited. 
business administration majors, allowing students to learn more independently, and truly realize personalized education and teaching. Finally, the teaching platform model built by "Internet + Education" allows teachers and students to speak and comment freely, and also allows administrative agencies to monitor teaching through network data, which greatly improves the rigor of network teaching and guarantees network teaching Benign development.

\section{The application status of "Internet + education" in the teaching of business administration}

Nowadays, the overall teaching framework of "Internet + Education" is basically completed, and some positive feedbacks have been received in teaching. However, there are still some problems in practical application. Educational researchers should focus on these problems for the follow-up network Be prepared for teaching improvement. The more common problems mainly include the following points: First, there is excessive dependence on "Internet + education", and some teachers even completely deny traditional teaching. The status and role of teachers in the teaching of business administration in colleges and universities is very important. Teachers' experience teaching can save students from taking many detours. Although the "Internet + education" model can make students more free to learn, this The state of "stocking" learning is difficult to control students. Therefore, traditional classroom teaching cannot be completely denied, and the two need to be effectively combined. Second, there is a lack of excellent educational shared resources. The core concept of "Internet + Education" is the sharing of educational resources. Students and teachers can use the Internet to observe and learn from the lectures of outstanding teachers to optimize teaching resources. However, in actual teaching, network teaching resources do not fit the current teaching content very well, and the teaching content recorded by teachers themselves is relatively rough, it is difficult to meet the learning needs of students, and affect the development of network teaching. Thirdly, online teaching places high demands on students' self-control. Although "Internet + education" can eliminate the restrictions of time and space in teaching, the supervision of students is relatively loose, and students' learning depends on the consciousness and self-discipline of students. It is difficult for teachers to control the real learning conditions of students, which will cause subsequent teaching design. Great influence.

\section{Research on the reform of "Internet + education" in the teaching of business administration}

In the environment of "Internet + education", college education and teaching opportunities and challenges coexist, and teaching reform should be carried out in accordance with its own development characteristics. Specifically, the following points can be started: First, teachers update teaching concepts. "Internet + education" makes teaching activities more diversified. Its emergence allows both students and teachers to effectively use the daily fragmented time, which greatly improves student learning efficiency and allows more open teaching Activities, to guide students to correctly use network tools to participate in the activity teaching. Secondly, teachers should pay attention to the complementation of online teaching and traditional classroom teaching, combining the advantages of the two, and offsetting the shortcomings and deficiencies of the two teaching. For business administration majors, although traditional teaching is very systematic and teachers have a more comprehensive grasp of students' learning progress, the overall teaching atmosphere is too rigid, and due to time and space constraints, it is difficult for teachers to deal with problems. In-depth explanation, the teaching content is mostly limited to textbooks, and students are not motivated to learn. While network teaching is rich in content and flexible in learning time, it can effectively cultivate students' learning autonomy, but it is difficult to effectively supervise students and cannot fully understand their learning progress. Therefore, only by effectively combining the two can the teaching quality of business administration be improved to the greatest extent.

\section{Concluding remarks}

Now that my country is in a critical period of education reform, strengthening the use of the "Internet + education" model and exploring the core of "Internet + education" is an important prerequisite for ensuring the effectiveness of college education and teaching. In the education and teaching of business administration majors in colleges and univer- 
sities, teachers should update their own teaching concepts, study and explore the similarities and differences between online teaching and traditional teaching, maximize students' learning enthusiasm, cultivate students' good self-study habits, and realize "Internet + education" "The organic integration with traditional teaching will improve the teaching quality of business administration and cultivate more innovative professionals.

\section{References}

1. Li Xiaomei, Liu Xiaowei, He Kui. Research and Practice on the Teaching Reform of Business Administration Courses under the Background of "Internet + Education"[J]. Heilongjiang Education: Higher Education Research and Evaluation, 2018, No.1254(08):7-8 .

2. Li Binyu. Research and Practice on the Teaching Reform of Business Administration Courses under the Background of "Internet + Education”[J]. Management Scientist, 2019, 000(010): P.145-146.

3. Han Yan. Research and Practice on the Teaching Reform of Business Administration Courses under the Background of "Internet + Education”[J]. Curriculum Education Research, 2019(21):34-34. 